DOI: $10.15193 /$ zntj/2017/111/191

\author{
MAGDALENA OLEKSY, ELŻBIETA KLEWICKA
}

\title{
SELEKCJA BAKTERII Z RODZAJU LACTOBACILLUS WYDAJNYCH W SYNTEZIE EGZOPOLISACHARYDÓW
}

\begin{abstract}
Streszczenie
Egzopolisacharydy (EPS) bakterii z rodzaju Lactobacillus charakteryzują się korzystnymi właściwościami prozdrowotnymi, dzięki którym mogą być stosowane jako funkcjonalne składniki żywności. Ich wykorzystanie na skalę przemysłową jest jednak utrudnione ze względu na wysoki koszt oraz niską wydajność produkcji. Odpowiedni dobór szczepów wydajnych w syntezie EPS może znacznie zwiększyć szansę ich wykorzystania w technologii żywności. Celem pracy była selekcja szczepów bakterii z rodzaju Lactobacillus zdolnych do wydajnej syntezy egzopolisacharydów zarówno w formie śluzu, jak i otoczek polisacharydowych. Na podstawie przeprowadzonych analiz makro- i mikroskopowych spośród 58 szczepów wytypowano trzy szczepy z gatunku Lactobacillus rhamnosus (LOCK 0943, LOCK 0935 oraz OM1) o najkorzystniejszych cechach wpływających na właściwości reologiczne podłoża hodowlanego. W pracy wykazano, że szczepy te mogą stanowić wydajne narzędzie w produkcji bakteryjnych egzpolisacharydów. Badane bakterie syntetyzują EPS w ilości $68 \div 137 \mathrm{mg} / \mathrm{l}$ w zależności od rodzaju źródła węgla. Zatem skład podłoża hodowlanego jest jednym z czynników determinujących wydajność syntezy EPS przez bakterie z rodzaju Lactobacillus.
\end{abstract}

Słowa kluczowe: Lactobacillus sp., selekcja, egzopolisacharydy (EPS), otoczki polisacharydowe (CPS), śluz (SPS)

\section{Wprowadzenie}

W ciągu ostatnich lat wśród naukowców wzrosło zainteresowanie egzopolisacharydami (EPS) bakteryjnymi ze względu na ich wszechstronne właściwości fizykochemiczne oraz biologiczne. Egzopolisacharydy są to wielkocząsteczkowe, długołańcuchowe biopolimery, składające się z powtarzających się jednostek sacharydowych połączonych wiązaniami $\alpha$-i $\beta$-glikozydowymi. Syntetyzowane egzopolisacharydy mogą być fizycznie związane z komórką bakteryjną, tworząc otoczkę polisacharydową

Mgr inż. M. Oleksy, dr hab. inż. E. Klewicka, Instytut Technologii Fermentacji i Mikrobiologii, Wydz. Biotechnologii i Nauk o Żywności, Łódź, Politechnika Łódzka, ul. Wólczańska 171/173, 90-924 Łódź. Kontakt:magdalena.oleksy@dokt.p.lodz.pl 
(CPS - capsular polysaccharides) lub mogą być luźno wydzielane do środowiska, tworząc śluz (SPS - slime polysaccharides) [7, 8]. Egzopolisacharydy wykorzystywane są jako substancje zagęszczające, stabilizujące i wiążące, dzięki ich nienewtonowskim właściwościom [5].

Bakterie z rodzaju Lactobacillus nie należą do wysokowydajnych producentów egzopolisacharydów, jednak mają ogromny potencjał ze względu na to, że są uznawane za bezpieczne dla zdrowia i życia człowieka (GRAS - generally recognized as a safe). Jak dotąd zidentyfikowano ok. 30 gatunków bakterii z rodzaju Lactobacillus produkujących EPS, jednak do najlepiej poznanych należą: $L b$. casei, Lb. acidophilus, Lb. brevis, Lb. curvatus, Lb. delbrueckii subsp. bulgaricus, Lb. helveticus, Lb. rhamnosus, Lb. plantarum i Lb. johnsonii [1, 21]. EPS bakterii Lactobacillus sp. odgrywają kluczową rolę w technologii wytwarzania fermentowanych produktów spożywczych, w szczególności fermentowanych produktów mlecznych. Wpływają na poprawę właściwości reologicznych oraz na smak produktów końcowych, takich jak sery czy jogurty. Mimo że EPS nie mają własnego smaku, to jednak zwiększają wrażenia smakowe odczuwane przez konsumentów. Dowiedziono, że oprócz właściwości technologicznych, EPS bakterii z rodzaju Lactobacillus charakteryzują się również właściwościami prozdrowotnymi, m.in. immunomodulującymi, przeciwnowotworowymi, prebiotycznymi, obniżającymi stężenie cholesterolu we krwi, obniżającymi ciśnienie krwi i przeciwwrzodowymi $[1,12,17]$. Zdolność danych szczepów Lactobacillus sp. do syntezy EPS wpływa także na wzmocnienie ich właściwości probiotycznych [14].

Mimo że egzopolisacharydy bakterii Lactobacillus sp. mają wiele korzystnych właściwości technologicznych oraz prozdrowotnych, wykorzystywanych m.in. w przemyśle spożywczym, farmaceutycznym oraz kosmetycznym, to ich produkcja nadal jest ograniczona [19]. Niska wydajność produkcji, wysoki koszt pozyskiwania oraz metod analizy strukturalnej EPS stanowią motywację do ciągłego poszukiwania szczepów wydajnych w syntezie EPS. Liczne badania wskazują na to, że wydajność syntezy egzopolisacharydów bakteryjnych w znacznym stopniu zależy od warunków prowadzonego procesu oraz składu podłoża hodowlanego. Zatem kolejnym krokiem w badaniach nad EPS jest optymalizacja warunków hodowli w celu uzyskania wydajnej syntezy z uwzględnieniem parametrów ekonomiczno-technicznych $[12,15]$.

Celem pracy była selekcja szczepów bakterii z rodzaju Lactobacillus, spośród 58 kultur zdolnych do wydajnej syntezy egzopolisacharydów, przy użyciu metod makroskopowych (wzrost w pożywce płynnej i stałej) oraz analizy mikroskopowej. 


\section{Material i metody badań}

\section{Materiat biologiczny}

Materiał biologiczny stanowiło 58 szczepów bakterii z rodzaju Lactobacillus przedstawionych $\mathrm{w}$ tab. 1 . Szczepy do badań hodowano w podłożu płynnym oraz na podłożu stałym MRS (DeMan, Rogosa, \& Sharpe, Merck, Niemcy) przez $48 \mathrm{~h}$ w temp. 37 lub $30^{\circ} \mathrm{C}$ w warunkach anaerobowych.

Tabela 1. Szczepy bakterii z rodzaju Lactobacillus stosowane do badań dotyczących syntezy egzopolisacharydów

Table 1. Strains of Lactobacillus sp. used to study synthesis of exopolysaccharides

\begin{tabular}{|c|c|c|c|c|c|}
\hline $\begin{array}{l}\text { L.p. } \\
\text { No. }\end{array}$ & $\begin{array}{c}\text { Gatunek } \\
\text { Genus }\end{array}$ & $\mathrm{Nr} / \mathrm{No}$. & $\begin{array}{l}\text { L.p. } \\
\text { No. }\end{array}$ & $\begin{array}{c}\text { Gatunek } \\
\text { Genus }\end{array}$ & $\mathrm{Nr} / \mathrm{No}$. \\
\hline 1. & Lb. acidophilus & ŁOCK 0939 & 30 & Lb. casei & ŁOCK 0904 \\
\hline 2. & Lb. acidophilus & ŁOCK 0928 & 31 & Lb. paracasei & ŁOCK O920 \\
\hline 3. & Lb. acidophilus & ŁOCK 0942 & 32 & Lb. paracasei & ŁOCK 0912 \\
\hline 4. & Lb. acidophilus & ŁOCK 0842 & 33 & Lb. casei & ŁOCK 0902 \\
\hline 5. & Lb. acidophilus & ŁOCK 0938 & 34 & Lb. rhamnosus & ŁOCK 0908 \\
\hline 6. & Lb. acidophilus & ŁOCK 0934 & 35 & Lb. casei & ŁOCK 0907 \\
\hline 7. & Lb. casei & ŁOCK 0848 & 36 & Lb. paracasei & ŁOCK 0924 \\
\hline 8 & Lb. acidophilus & ŁOCK 0933 & 37 & Lb. casei & ŁOCK 0911 \\
\hline 9 & Lb. rhamnosus & ŁOCK 0943 & 38 & Lb. casei & ŁOCK 0903 \\
\hline 10 & Lb. acidophilus & ŁOCK 0931 & 39 & Lb. casei & ŁOCK 0910 \\
\hline 11 & Lb. acidophilus & ŁOCK 0930 & 40 & Lb. casei & ŁOCK 0909 \\
\hline 12 & Lb. casei & ŁOCK 0905 & 41 & Lb. paracasei & ŁOCK 0922 \\
\hline 13 & Lb. rhamnosus & ŁOCK 0935 & 42 & Lb. paracasei & ŁOCK 0913 \\
\hline 14 & Lb. paracasei & ŁOCK 0914 & 43 & Lb. casei & ŁOCK 1020 \\
\hline 15 & Lb. casei & NCDO 206 & 44 & Lb.casei & ŁOCK 0919 \\
\hline 16 & Lb. acidophilus & ŁOCK 0927 & 45 & Lb. casei & ŁOCK 0906 \\
\hline 17 & Lb. acidophilus & ŁOCK 0936 & 46 & Lb. brevis & ŁOCK 0944 \\
\hline 18 & Lb. delbrueckii & ŁOCK 0854 & 47 & Lb. pentosus & ŁOCK 0979 \\
\hline 19 & Lb. acidophilus & ŁOCK 0937 & 48 & Lb. brevis & ŁOCK 0980 \\
\hline 20 & Lb. acidophilus & ŁOCK 0929 & 49 & Lb. plantarum & ŁOCK 0981 \\
\hline 21 & Lb. acidophilus & ŁOCK 0941 & 50 & Lb. plantarum & ŁOCK 0982 \\
\hline 22 & Lb. acidophilus & ŁOCK 0840 & 51 & Lb. brevis & ŁOCK 0983 \\
\hline 23 & Lb. acidophilus & ŁOCK 0932 & 52 & Lb. brevis & ŁOCK 0984 \\
\hline 24 & Lb. rhamnosus & OM-1 [13] & 53 & Lb. paracasei & ŁOCK 0985 \\
\hline 25 & Lb. acidophilus & ŁOCK 0926 & 54 & Lb. delbrueckii & ŁOCK 0987 \\
\hline 26 & Lb. paracasei & ŁOCK 0921 & 55 & Lb. mисоsae & ŁOCK 0988 \\
\hline 27 & Lb. paracasei & ŁOCK 0917 & 56 & Lb. plantarum & ŁOCK 0989 \\
\hline 28 & Lb. paracasei & ŁOCK 0918 & 57 & Lb. plantarum & ŁOCK 0990 \\
\hline 29 & Lb. casei & ŁOCK 0901 & 58 & Lb. pentosus & ŁOCK 0991 \\
\hline
\end{tabular}

Objaśnienia / Explanatory notes:

ŁOCK - Kolekcja Czystych Kultur Przemysłowych ŁOCK 105 (Łódź, Polska) / Collection of Pure Industrial Culture (Łódź, Poland); NCDO - National Collection of Dairy Organisms (Great Britain) 
Produkcja EPS w formie śluzu (SPS)

Zdolność badanych bakterii do syntezy EPS w formie śluzu poddawano ocenie makroskopowej. W tym celu wykonywano hodowle bakteryjne na podłożu stałym oraz płynnym MRS (de Man, Rogosa, Sharpe, Merc, Niemcy). Hodowle inkubowano przez $48 \mathrm{~h} \mathrm{w}$ temp. $37^{\circ} \mathrm{C}$ w warunkach tlenowych. Po inkubacji poddawano ocenie makroskopowej zdolność bakterii do tworzenia gładkich kolonii o powierzchni śluzowatej i błyszczącej na podłożu stałym oraz zdolność do tworzenia śluzu w podłożu płynnym. Lepkość hodowli ustalano w teście ,nitki” poprzez dotknięcie hodowli sterylną ezą.

Produkcja EPS w formie otoczek (CPS)

Otoczki polisacharydowe badanych bakterii obserwowano pod mikroskopem świetlnym po zabarwieniu komórek bakteryjnych barwnikiem zasadowym oraz tła barwnikiem kwasowym (barwienie negatywno-pozytywne). W tym celu zastosowano barwienie Manevala [9]. Za pomocą sterylnej ezy nanoszono na szkiełko podstawowe kroplę czerwieni Kongo. Następnie mieszano z nią kolonię bakteryjną z hodowli na podłożu stałym lub kroplę płynnej hodowli bakteryjnej w bulionie MRS. Preparat wysuszano w powietrzu i następnie zanurzano rozmaz w roztworze Manevala. Po 5 min barwnik delikatnie wypłukiwano wodą destylowaną. Otrzymany preparat po wysuszeniu na powietrzu oglądano pod obiektywem imersyjnym $(\times 100)$.

\section{Analiza wydajności syntezy EPS}

Płynne podłoże MRS zaszczepiano inoculum (10\% v/v). Po $48 \mathrm{~h}$ inkubacji próbki podgrzewano w łaźni wodnej (temp. $100{ }^{\circ} \mathrm{C}, 15 \mathrm{~min}$ ) w celu inaktywacji enzymów. Następnie komórki bakteryjne oraz skoagulowane białka odwirowywano (15 min, $14534 \times \mathrm{g}, \quad 4{ }^{\circ} \mathrm{C}$ ), po czym do supernatantu dodawano dwie objętości 96procentowego etanolu w celu wytrącenia EPS. Próbki inkubowano przez $24 \mathrm{~h} \mathrm{w}$ temp. $4{ }^{\circ} \mathrm{C}$. Osad egzopolisacharydów zbierano przez odwirowanie próbek (20 min, $11772,54 \times \mathrm{g}$, temp. $4^{\circ} \mathrm{C}$ ) i rozpuszczano w wodzie destylowanej.

Zawartość egzopolisacharydów w próbce oznaczano zmodyfikowaną metodą kolorymetryczną Dubois z użyciem glukozy jako wzorca [3]. $1 \mathrm{ml}$ próbki badanej mieszano z $0,5 \mathrm{ml} 5$-procentowego wodnego roztworu fenolu ( $5 \mathrm{~g} / 100 \mathrm{ml}$ wody destylowanej). Następnie dodawano 2,5 ml 95-procentowego kwasu siarkowego(VI). Próbki inkubowano w temp. $20 \pm 2{ }^{\circ} \mathrm{C}$ przez $10 \mathrm{~min}$, po czym każdą próbę mieszano przez $30 \mathrm{~s}$. Wymieszane próbki poddawano inkubacji przez 20 min w łaźni wodnej o temp. $25{ }^{\circ} \mathrm{C}$. Po tym czasie dokonywano pomiaru absorbancji przy długości fali $\lambda=490 \mathrm{~nm}$. Próbę kontrolną stanowiła woda destylowana $(1 \mathrm{ml})$. Wszystkie analizy wykonywano w trzech niezależnych powtórzeniach. Wyniki przedstawiono jako średnią arytmetyczną z 3 powtórzeń wraz z odchyleniem standardowym. 
W celu określenia czy różnice pomiędzy wynikami badań są statystycznie istotne wykonano test istotności różnic ANOVA $(\mathrm{p}=0,05)$ za pomocą programu Origin Pro 2017.

\section{Wyniki i dyskusja}

W pierwszym etapie badań wykazano, że fenotyp $60 \%$ badanych szczepów można opisać jako śluzowaciejący. Te właściwości fenotypowe mogą być związane ze zdolnością badanych szczepów do syntezy EPS [6]. Ocena makroskopowa hodowli bakteryjnych jest jedną z najprostszych metod wykorzystywanych w selekcji bakterii syntetyzujących EPS. Jest to jednak metoda mało czuła, ponieważ nie jest możliwe zidentyfikowanie za jej pomocą szczepów, które produkują niewielkie ilości tych biopolimerów [18]. Obserwacji poddano produkcję EPS do podłoża w postaci gęstej, lepkiej zawiesiny (fot. 1A: 1, 2, 4). Przy takich hodowlach napotykano znaczną trudność w dokładnym wymieszaniu prób. Największą lepkością charakteryzowały się hodowle trzech szczepów: Lb. rhamnosus ŁOCK 0943, Lb. rhamnosus ŁOCK 0935 oraz Lb. rhamnosus OM-1. Z kolei na podstawie badań makroskopowych stwierdzono, że aż 16 szczepów nie wykazywało zdolności do syntezy EPS w formie śluzu lub produkowało je w bardzo niewielkiej ilości (fot. 1A: 3). Należały do nich szczepy: Lb. acidophilus ŁOCK 0933, Lb. acidophilus ŁOCK 0931, Lb. acidophilus ŁOCK 0930, Lb. casei ŁOCK 0905, Lb. casei NCDO 206, Lb. acidphilus ŁOCK 0937, Lb. acidophilus ŁOCK 0941, Lb. casei ŁOCK 0902, Lb. casei ŁOCK 0907, Lb. paracasei ŁOCK 0924, Lb. paracasei ŁOCK 0922, Lb. paracasei ŁOCK 0913, Lb. casei ŁOCK 1020, Lb. pentosus ŁOCK 0979, Lb. brevis ŁOCK 0980, Lb. plantarum ŁOCK 0989.

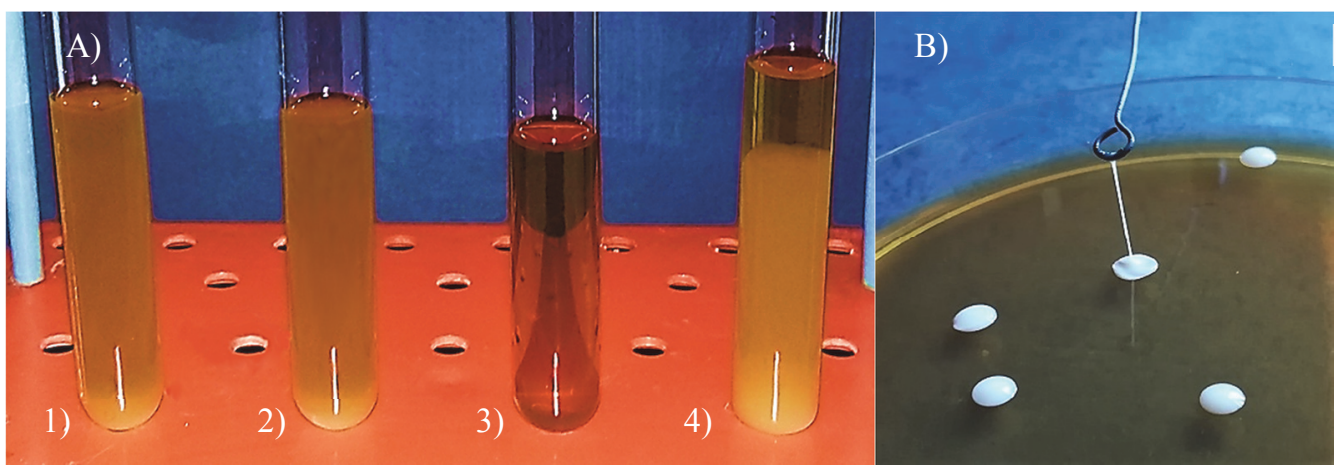

Fot. 1. Wzrost bakterii z rodzaju Lactobacillus A) w podłożu płynnym: 1) Lb. rhamnosus ŁOCK 0943, 2) Lb. paracasei ŁOCK 0914, 3) Lb. paracasei ŁOCK 0924, 4) Lb. rhamnosus ŁOCK 0935; B) na podłożu stałym - makroskopowy wygląd śluzowaciejącego szczepu Lb. rhamnosus OM-1

Photo 1. Lactobacillus sp. A) growing in liquid medium: 1) Lb. rhamnosus ŁOCK 0943, 2) Lb. paracasei ŁOCK 0914, 3) Lb. paracasei ŁOCK 0924, 4) Lb. rhamnosus ŁOCK 0935; B) on agar medium: macroscopic image of strand formed by the cellular mass of EPS-producing Lb. rhamnosus OM1 strain 
Kolejny etap badań selekcyjnych obejmował ocenę makroskopową kolonii bakteryjnych na podłożu stałym MRS. Spośród 58 badanych szczepów jedynie $7-L b$. acidophilus ŁOCK 0942, Lb. acidophilus ŁOCK 0934, Lb. rhamnosus ŁOCK 0935, Lb. paracasei ŁOCK 0914, Lb. acidophilus ŁOCK 0936, Lb. rhamnosus ŁOCK 0943, Lb. rhamnosus OM-1 - tworzyło na podłożu agarowym gładkie kolonie o powierzchni śluzowatej i błyszczącej, które po dotknięciu sterylną ezą tworzyły charakterystyczną lepką nić (fot. 1B).

Kolejny etap badań stanowiła ocena zdolności badanych szczepów bakterii z rodzaju Lactobacillus do syntezy egzopolisacharydów w formie otoczek (CPS). Otoczki polisacharydowe obserwowano pod mikroskopem po wybarwieniu preparatów mikroskopowych metodą Manevala. Jest to barwienie negatywno-pozytywne, podczas którego komórki bakteryjne wybarwiają się na różowo, a otoczki polisacharydowe pozostają przezroczyste (białe) na granatowym tle (fot. 2). Otoczek polisacharydowych nie zaobserwowano u 12 szczepów spośród 58 badanych. Były to szczepy: Lb. acidophilus ŁOCK 0933, Lb. acidophilus ŁOCK 0931, Lb. acidophilus ŁOCK 0927, Lb. acidophilus ŁOCK 0929, Lb. acidophilus ŁOCK 0941, Lb. paracasei ŁOCK 0912, Lb. paracasei ŁOCK 0922, Lb. casei ŁOCK 1020, Lb. casei ŁOCK 0906, Lb. plantarum ŁOCK 0981, Lb. paracasei ŁOCK 0985, Lb. plantarum ŁOCK 0991. Z kolei najlepszymi producentami CPS okazały się szczepy: Lb. acidophilus ŁOCK 0942, Lb. rhamnosus ŁOCK 0943, Lb. rhamnosus ŁOCK 0935, Lb. acidophilus ŁOCK 0936 oraz Lb. rhamnosus OM-1.

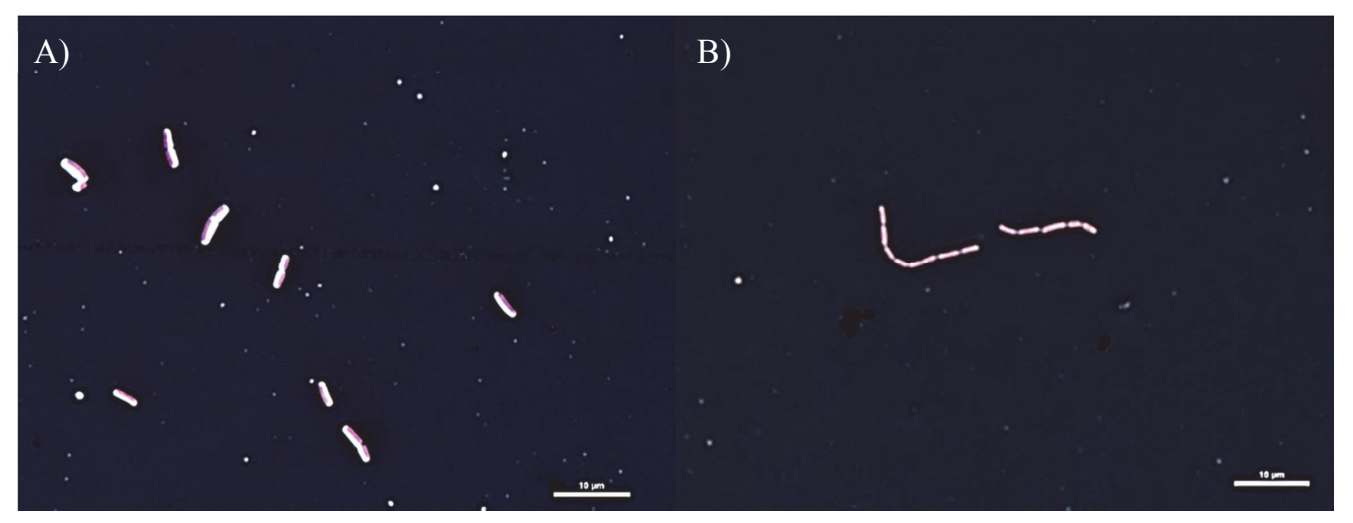

Fot. 2. A) Mikroskopowy obraz otoczek polisacharydowych Lb. acidophilus ŁOCK 0937; B) mikroskopowy obraz komórek bakteryjnych Lb. paracasei ŁOCK 0922 nieprodukujących otoczek polisacharydowych (komórka bakteryjna jest wybarwiona na różowo, tło na ciemny granat, otoczka pozostaje przezroczysta)

Photo 2. A) Photomicrograph of the polysaccharide capsules of Lb. acidophilus LOCK 0937; B) Photomicrograph of Lb. paracasei LOCK 0922 strain which is not capable of producing CPS (bacterial cell is pink stained; background is dark grenade; CPS remains transparent) 
W ostatnim etapie badań skriningowych porównano zdolność badanych szczepów bakterii Lactobacillus sp. do syntezy egzopolisacharydów zarówno w formie CPS, jak i SPS. Wykazano, że wśród badanych szczepów jedynie 5 nie wykazywało zdolności do syntezy EPS. Były to szczepy: Lb. acidophilus ŁOCK 0933, Lb. acidophilus ŁOCK 0931, Lb. acidophilus ŁOCK 0941, Lb. paracasei ŁOCK 0922, oraz Lb. casei ŁOCK 1020. Wykazano, że zdolność do syntezy egzopolisacharydów w formie CPS nie determinuje zdolności do produkcji SPS i na odwrót. M.in. w hodowli szczepów: $L b$. acidophilus ŁOCK 0930, Lb. casei ŁOCK 0905, Lb. casei ŁOCK 0905, Lb. acidophilus ŁOCK 0937, Lb. casei ŁOCK 0902, Lb. casei ŁOCK 0907, Lb. paracasei ŁOCK 0924, Lb. paracasei ŁOCK 0913, Lb. pentosus ŁOCK 0979, Lb. brevis ŁOCK 0980, Lb. plantarum ŁOCK 0989 nie zaobserwowano syntezy SPS, natomiast w preparatach mikroskopowych zaobserwowano zdolność do syntezy otoczek polisacharydowych. Z kolei szczepy: Lb. acidophilus ŁOCK 0927, Lb. acidophilus ŁOCK 0929, Lb. paracasei ŁOCK 0912, Lb. casei ŁOCK 0906, Lb. plantarum ŁOCK 0981, Lb. paracasei ŁOCK 0985, Lb. plantarum ŁOCK 0991 charakteryzowały się zdolnością do syntezy egzopolisacharydów jedynie w formie CPS.

Na podstawie przeprowadzonych badań selekcyjnych wytypowano 3 szczepy do dalszych badań nad EPS, które charakteryzowały się najkorzystniejszymi cechami wpływającymi na właściwości reologiczne podłoża hodowlanego: Lb. rhamnosus ŁOCK 0943, ŁOCK 0935 oraz OM-1. W przeprowadzonej ocenie makroskopowej dowiedziono, że szczepy te charakteryzowały się najwyższą wydajnością w syntezie egzopolisacharydów (SPS oraz CPS) wśród 58 badanych szczepów. Zatem zdolność do syntezy EPS jest cechą indywidualną szczepu. Jak podają Badel i wsp. [1], $L b$. rhamnosus typuje się jako najwydajniejszego producenta wśród Lactobacillus sp. Macedo i wsp. [11] dowiedli, że szczep Lb. rhamnosus 9595 wykazuje zdolność do syntezy EPS w ilości nawet 2,7 g/l podłoża hodowlanego, na podłożu z białkiem serwatkowym. Aby potwierdzić zdolność badanych bakterii do wydajnej syntezy egzopolisacharydów oznaczono ilość EPS w podłożu hodowlanym. Bakterie z rodzaju Lactobacillus należą do bakterii fermentacji mlekowej, które jako jedne z niewielu mają zdolność fermentacji laktozy. $Z$ tego względu do dalszych badań wykorzystano podłoża z dodatkiem laktozy oraz jej monomerów: glukozy oraz galaktozy w ilości 20 g/l. Po ekstrakcji badanych polimerów z podłoża za pomocą 96-procentowego etanolu ich ilość mierzono metodą Dubois, przy użyciu glukozy jako wzorca. Wykazano, że Lb. rhamnosus ŁOCK 0943 syntetyzował ok. $85 \div 95 \mathrm{mg} / \mathrm{l}$ EPS, zarówno w podłożu z dodatkiem laktozy, glukozy, jak i galaktozy (rys. 1). Z kolei w przypadku $L b$. rhamnosus ŁOCK 0935 zaobserwowano większą wydajność syntezy EPS w podłożu z glukozą i laktozą $(103 \div 109 \mathrm{mg} / \mathrm{l})$ niż w próbie z galaktozą $(83 \mathrm{mg} / \mathrm{l})$. Nie stwierdzono jednak różnic statystycznie istotnych pomiędzy wynikami otrzymanymi w przypadku szczepów Lb. rhamnosus ŁOCK 0943 oraz Lb. rhamnosus ŁOCK 0935. Odno- 
towano je jedynie pomiędzy wynikami efektywności syntezy EPS przez $L b$. rhamnosus OM-1 (rys. 1). Najniższą wydajność syntezy EPS przez ten szczep odnotowano w hodowli z dodatkiem laktozy (69 mg/l). Z kolei w hodowli z sacharydami: glukozą lub galaktozą zaobserwowano wydajność na poziomie ok. $135 \mathrm{mg} / \mathrm{l}$.

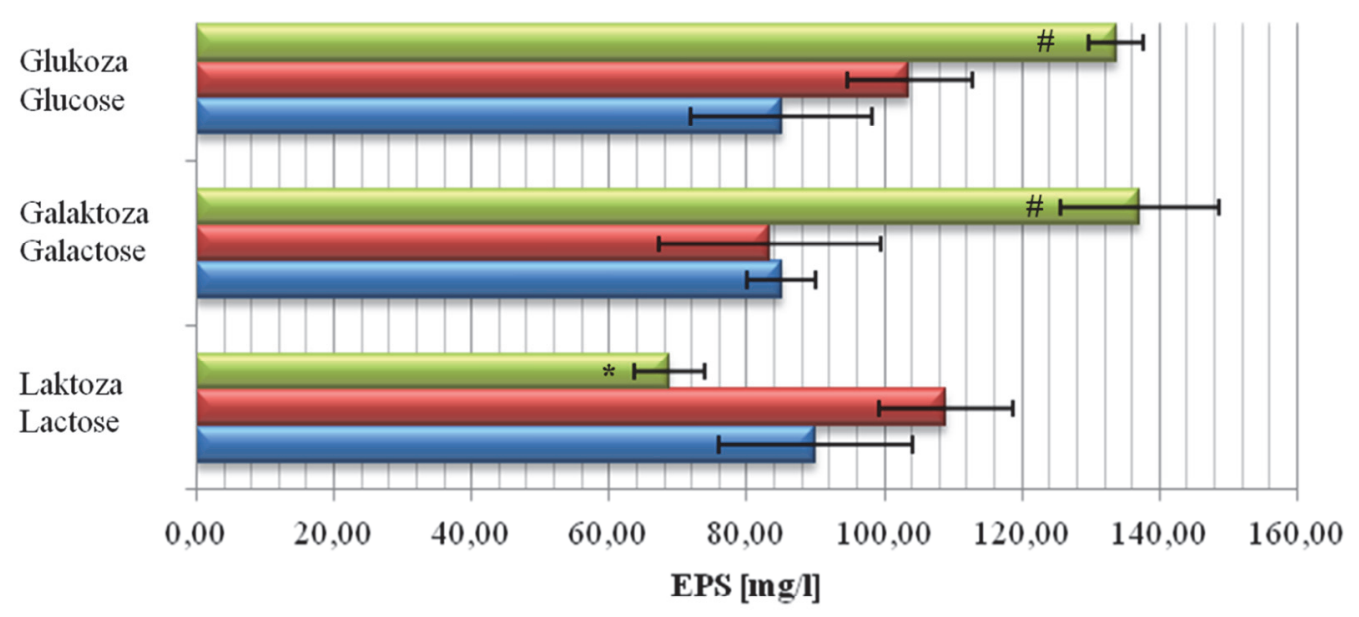

$\square$ Lb. rhamnosus OM-1 $\square$ Lb. rhamnosus LOCK $0935 \square$ घb. rhamnosus LOCK 0943

Objaśnienia: Explanatory notes:

*, \# - różnice statystycznie istotne między średnimi wartościami wyprodukowanych egzopolisacharydów przez te same szczepy $L b$. rhamnosus, hodowane na różnych źródłach węgla $(\mathrm{p} \leq 0,05) /$ the statistically significant differences between mean values of amounts of exopolysaccharides produced by the same $L b$. rhamnosus strains but cultured on different carbon source.

Rys. 1. Wpływ źródła węgla na produkcję egzopolisacharydów przez Lb. rhamnosus ŁOCK 0935, ŁOCK 0934 oraz OM-1

Fig. 1. Effect of carbon source on production of exopolysaccharides by Lb. rhamnosus ŁOCK 0935, ŁOCK 0934 and OM-1

Wyniki własne są zbliżone do wyników, które otrzymali Landersjö i wsp. [10]. Lb. rhamnosus GG rosnący w mleku, badany przez ten zespół, wytwarzał jedynie 80 g/l EPS. Z kolei Polak-Berecka i wsp. [16] uzyskali nieznacznie wyższe wyniki wydajności EPS. Badany przez nich szczep Lb. rhamnosus E/N syntetyzował EPS w podłożu z glukozą w ilości $185 \mathrm{mg} / 1$, z laktozą - $153 \mathrm{mg} / \mathrm{l}$, a w podłożu z galaktozą - $165 \mathrm{mg} / 1$. Z kolei Dupont i wsp. [4] osiągnęli wydajność 10-krotnie większą $1000 \mathrm{mg} / 1$ EPS wytworzonych przez Lb. rhamnosus 9595 M na podłożu BMM (Basal Minimal Medium).

Na podstawie przeprowadzonych badań wstępnie można wskazać, że wydajność syntezy EPS w znacznej mierze zależy od składu podłoża hodowlanego. Do takich 
wniosków doszli również van den Berg i wsp. [20] oraz Deepak i wsp. [2], którzy badali wpływ warunków hodowli na syntezę egzopolisacharydów przez bakterie z rodzaju Lactobacillus (Lb. sake 0-1 oraz Lb. acidophilus). Kolejnym etapem badań będzie optymalizacja warunków hodowli bakterii Lb. rhamnosus ŁOCK 0943, ŁOCK 0935 oraz OM-1 w celu zwiększenia wydajności syntezy egzopolisacharydów.

\section{Wnioski}

1. Ocena makroskopowa hodowli szczepów bakteryjnych stanowi prostą, tanią i efektywną metodę wstępnej selekcji bakterii wydajnie syntetyzujących egzopolisacharydy.

2. Zdolność do syntezy egzopolisacharydów w formie otoczek (CPS) nie determinuje zdolności do produkcji EPS w formie śluzu (SPS) i na odwrót.

3. Na podstawie przeprowadzonych badań selekcyjnych wytypowano 3 szczepy $L b$. rhamnosus (ŁOCK 0943, ŁOCK 0935 oraz OM-1) charakteryzujące się najwyższą wydajnością syntezy egzopolisacharydów (SPS oraz CPS), zatem zdolność do syntezy EPS jest cechą indywidualną szczepu.

4. Wydajność syntezy egzopolisacharydów badanych szczepów Lb. rhamnosus zależy od źródła węgla w podłożu hodowlanym.

\section{Literatura}

[1] Badel S., Bernardi T., Michaud P.: New perspectives for Lactobacilli exopolysaccharides. Biotechnol. Adv., 2011, 29, 54-66.

[2] Deepak V., Ram Kumar Pandian S., Sivasubramaniam S. D., Nellaiah H., Sundar K.: Optimization of anticancer exopolysaccharide production from probiotic Lactobacillus acidophilus by response surface methodology. Prep. Biochem. Biotechnol., 2016, 46 (3), 288-297.

[3] DuBois M., Gilles K.A., Hamilton J.K., Rebers P.A.T., Smith F.: Colorimetric method for determination of sugars and related substances. Anal. Chem., 1956, 28, 350-356.

[4] Dupont I., Roy D., Lapointe G.: Comparison of exopolysaccharide production by strains of Lactobacillus rhamnosus and Lactobacillus paracasei grown in chemically defined medium and milk. J. Ind. Microbiol. Biotechnol., 2000, 24, 251-255.

[5] Freitas F., Alves V.D., Reis M.M.A.: Advances in bacterial exopolysaccharides: From production to biotechnological applications. Trends Biotechnol., 2011, 29 (8), 388-396.

[6] Gomez J.: Characterization of exopolysaccharides produced by shalofilos microorganism belonging to the genera Halomonas, Alteromonas, Idiomarina, and Palleronia salipiger. $\mathrm{PhD}$ dissertation, University of Granada, Granada 2006.

[7] Górska S., Grycko P., Rybka J., Gamian A.: Egzopolisacharydy bakterii kwasu mlekowego biosynteza i struktura. Post. Hig. Med. Dośw., 2007, 61, 805-818.

[8] Kšonžeková P., Bystrický P., Vlčková S., Pätoprstý V., Pulzová L., Mudroňová D., Kubaškováa T., Csank T, Tkáčiková L.: Exopolysaccharides of Lactobacillus reuteri: Their influence on adherence of E. coli to epithelial cells and inflammatory response. Carbohydr. Polym., 2016, 141, 10-19.

[9] Kuzhiyil A., Lee Y., Shim A., Xiong A.: Osmotic stress induces kanamycin resistance in Escherichia coli B23 through increased capsule formation. J. Exp. Microbiol. Immunol., 2012, 16, 5-10.

[10] Landersjo C., Yang Z., Huttunen E., Widmalm G.: Structural studies of the exopolysaccharide produced by Lactobacillus rhamnosus strain GG (ATCC 53103). Biomacromolecules, 2002, 3, 880884. 
[11] Macedo M.G., Lacroix C., Gardner N.J., Champagne C.P.: Effect of medium supplementation on exopolysaccharide production by Lactobacillus rhamnosus RW-9595 M in whey permeate. Int. Dairy J., 2002, 12, 419-26.

[12] Nwodo U.U., Green E., Okoh A.I.: Bacterial exopolysacchardes: Functionality and prospects. Int. J. Mol. Sci., 2012, 13, 14002-14015.

[13] Oleksy M., Klewicka E. Lactobacillus rhamnosus strain OM-1, 16S ribosomal RNA gene, partial sequence. Accession number KY576903. GenBank National Center for Biotechnology Information database, 2016.

[14] Oleksy M., Klewicka E.: Exopolysaccharides produced by Lactobacillus sp. - biosynthesis and applications. Crit. Rev. Food Sci. Nutr., 2016, DOI: 10.1080/10408398.2016.1187112.

[15] Patel A., Prajapati J.B.: Food and health applications of exopolysaccharides produced by lactic acid bacteria. J. Adv. Dairy Res., 2013, 1, 1-7.

[16] Polak-Berecka M., Waśko A., Kubik-Komar A.: Optimization of culture conditions for exopolysaccharide production by a probiotic strain of Lactobacillus rhamnosus E/N. Pol. J. Microbiol., 2014, 63 (2), 253-257.

[17] Polak-Berecka M., Waśko A., Szwajgier D., Choma A.: Bifidogenic and antioxidant activity of exopolysaccharides produced by Lactobacillus rhamnosus E/N cultivated on different carbon sources. Pol. J. Microbiol., 2013, 62 (2), 181-189.

[18] Smitinont T., Tansakul C., Tanasupawat S., Keeratipibul S., Navarini L., Bosco M., Cescutti P.: Exopolysaccharide - producing lactic acid bacteria strains from traditional Thai fermented foods: Isolation, identification and exopolysaccharide characterization. Int. J. Food Microbiol., 1999, 51, 105-111.

[19] Trabelsi I., Slima B.S., Chaabane H., Riadh S.B.: Purification and characterization of a novel exopolysaccharides produced by Lactobacillus sp. Ca6. Int. J. Biol. Macromol., 2015, 74, 541-546.

[20] Van der Berg D.J.C., Smits A., Pot B., Ledeboer A.M., Kersters K., Verbakel J.M.A., Verrips C.T.: Isolation, screening and identification of lactic acid bacteria from traditional food fermentation processes and culture collections. Food Biotechnol., 1993, 7, 189-205.

[21] Widyastuti Y., Rohmatussolihat, Febrisiantosa A.: The role of lactic acid bacteria in milk fermentation. J. Food Nutr. Sci., 2014, 5, 425-434.

\title{
SCREENING OF EFFICIENT EXOPOLYSACCHARIDE-PRODUCING STRAINS OF LACTOBACILLUS SP.
}

\author{
$\mathrm{S} u \mathrm{~m}$ m a r y
}

Exopolysaccharides (EPS) produced by bacteria of the Lactobacillus genus are characterized by beneficial health-promoting properties owing to which EPS can be used as functional food ingredients. However, their utilization on an industrial scale is made difficult by high costs of their production and low productivity. A way to increase the prospect of utilizing EPS in food technology is to properly select strains that are efficient in the synthesis thereof. The objective of the research study was to select Lactobacillus strains capable of efficiently synthesizing EPS both in the form of slime and capsular polysaccharides. Based on the macro- and microscopic analyses, three Lactobacillus rhamnosus strains (LOCK 0943, ŁOCK 0935, and OM-1) were selected from among 58 lactobacilli strains; they had the most beneficial properties to impact the rheology of the culture medium. The study showed that those strains could be an effective tool in the production of bacterial exopolysaccharides. The tested bacteria synthesized 68 to 137 $\mathrm{mg} / \mathrm{L}$ of EPS depending on the type of carbon source. Thus, the composition of the culture medium is one of the factors to determine the efficiency of EPS synthesis by Lactobacillus bacteria.

Key words: Lactobacillus sp., screening, exopolysaccharides (EPS), capsular polysaccharides (CPS), slime (SPS) 